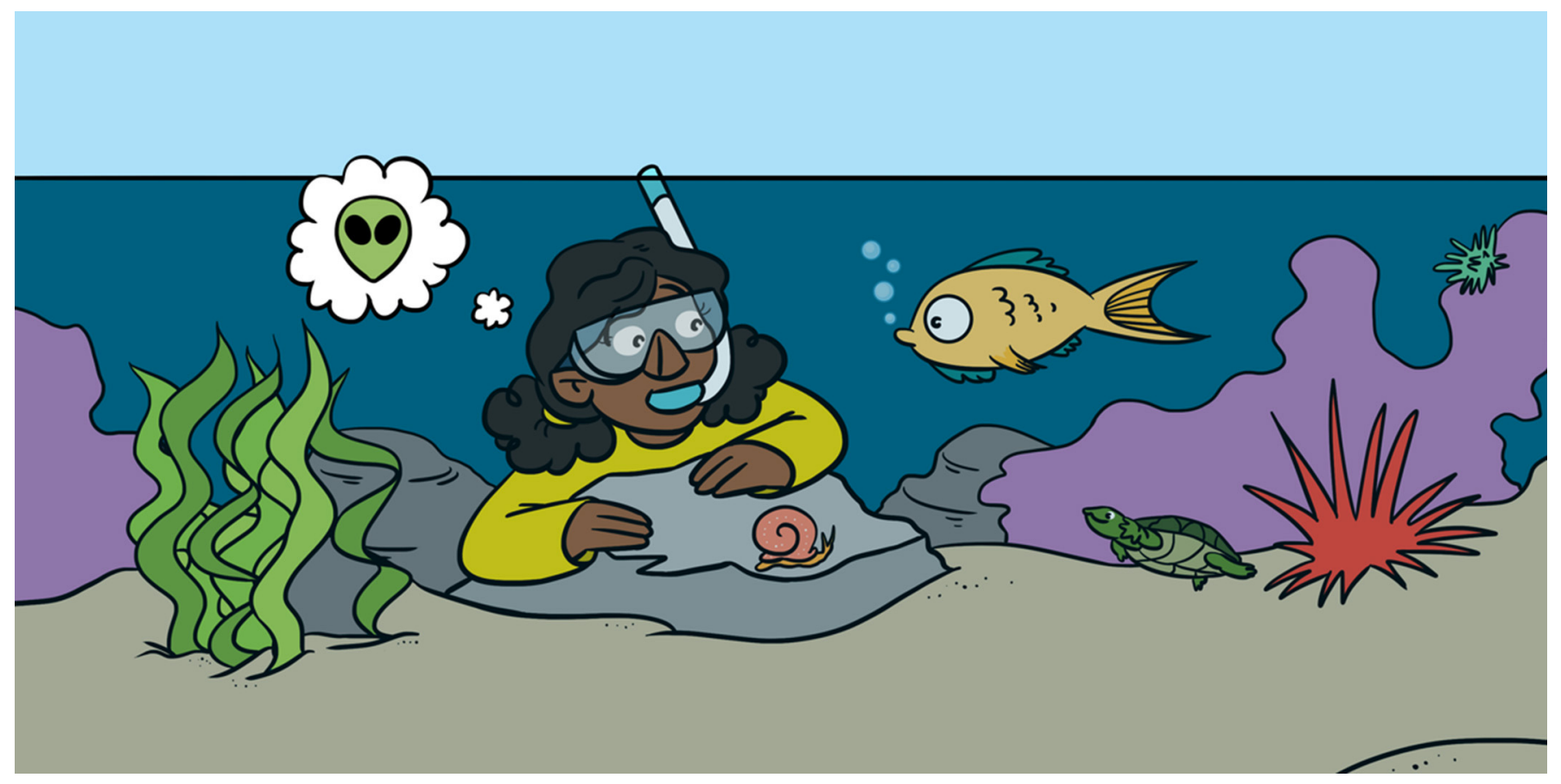

\title{
ALIENS FROM AN UNDERWATER WORLD
}

\author{
Pedro Morais ${ }^{1,2^{*}}$, João Encarnação ${ }^{1}$, Maria Alexandra Teodósio ${ }^{1}$ and Ester Dias ${ }^{2,3}$ \\ ${ }^{1}$ CCMAR-Centre of Marine Sciences, University of Algarve, Faro, Portugal \\ ${ }^{2}$ Institute of Environment, Florida International University, Miami, FL, United States \\ ${ }^{3}$ CIIMAR-Interdisciplinary Centre of Marine and Environmental Research, University of Porto, Porto, Portugal
}

\section{YOUNG REVIEWER:}

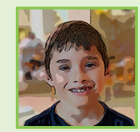

NIKO

AGE: 8
About 3.1 billion people around the world live within $100 \mathrm{~km}$ of the coastline. If you are one of those people, then you also live near an estuary. What you probably do not know is that many alien species live in this underwater world, and we are not talking about extraterrestrial species from outer space. Are you scared? Well, do not be! These alien species are from planet Earth. In this article, we will tell you what alien species are, why scientists study them, how any species may become an alien, and how a few alien species may become an invasive species. You will also learn how you can help scientists find and track alien species, and how to defeat them. Along the way, we will give examples of alien species living in the San Francisco Estuary in North America, a paradise for hundreds of alien species.

\section{WHAT ARE ALIEN SPECIES?}

When someone talks about aliens we immediately think about extraterrestrial life. But you can probably encounter aliens right outside your home, because alien species are all around us! Look up and 


\section{ALIEN SPECIES}

Species that live in nature but far away from their natural distribution range. Alien species cross geographical barriers like mountains, oceans, or deserts, with the help of humans.

\section{DISTRIBUTION} RANGE

The regions occupied by a species.

\section{NATIVE SPECIES}

Also called an indigenous species, a species that is present in the region where it has evolved and lived for thousands of years.

\section{ECOSYSTEM}

An area with distinctive characteristics where animals, plants, and other organisms interact with each other and the environment. Estuaries, deserts, and forests are examples of ecosystems. you may see the Eurasian collared dove flying above you. Under your feet, nightcrawlers may be squeezing their way through the soil toward their next meal. Right in front of your eyes, you may see full-grown Australian acacia trees that are easy to notice because of their yellow flowers. Aliens like the common carp are present underwater, swimming in the rivers alongside us.

If these are not aliens from outer space, what are they? Alien species are species that live in nature but far away from their natural distribution range. Species that live in their natural distribution range, the area where they evolved and adapted for thousands of years, are called native species or indigenous species. For a species to be called alien, it must have crossed geographical barriers like mountains, oceans, or deserts, with the help of humans. Some alien species were moved to new areas on purpose, but often their introduction into a new environment was accidental.

\section{WHY SHOULD SCIENTISTS STUDY ALIEN SPECIES?}

There are at least four important reasons for scientists to study alien species. The most important reason is to learn how to avoid introducing alien species into new ecosystems. Second, it is important to know if an alien species may harm the native species. For example, after the overbite clam (Figure 1I) was introduced into the San Francisco Estuary, the number of native shrimps and anchovies decreased. This happened because the overbite clam made the food of anchovies and shrimps less available [1]. Third, we need to learn how to best eliminate alien species, especially those that harm native species. Last, we need to know if an alien species may damage man-made structures. For example, in the San Francisco Estuary, a naval shipworm ate wooden wharves and ferry slips, which caused over $\$ 825$ million USD in losses during the first 7 years of its invasion [2].

\section{ALIENS IN THE ESTUARY}

The San Francisco Estuary is the biggest in California, United States, and home to thousands of plant and animal species. Some of these species came from distant regions. The first alien species identified in the San Francisco Estuary was the bay barnacle, found in samples collected in 1853 (Figure 1D). By the late 1990s, scientists estimated that four new alien species were calling the Estuary their new home every single year [2]. Two of the most recent alien species are a small fish called bluefin killifish, first detected in 2017, and a semiaquatic rodent called nutria, first detected in 2018 (Figures 2A,F) [3, 4].

The famous western mosquitofish was often introduced intentionally to eat the larvae of annoying mosquitoes. The first time it was found 
Figure 1

Some of the alien species present in the San Francisco Estuary and adjacent ecosystems

(A) Brazilian waterweed; (B) Atlantic pileworm; (C) sulpher boring sponge; (D) bay barnacle; (E) eastern mudsnail; (F) eastern oyster drill; (G) eastern white slippersnail; (H) amethyst gem clam; (I) overbite clam; (J) common Atlantic soft-shelled clam;

(K) Japanese clam;

(L) convex slippersnail;

(M) Pacific oyster;

(N) eastern oyster;

(O) Japanese mussel

(Photo credits:

BioDiversity4All.org).
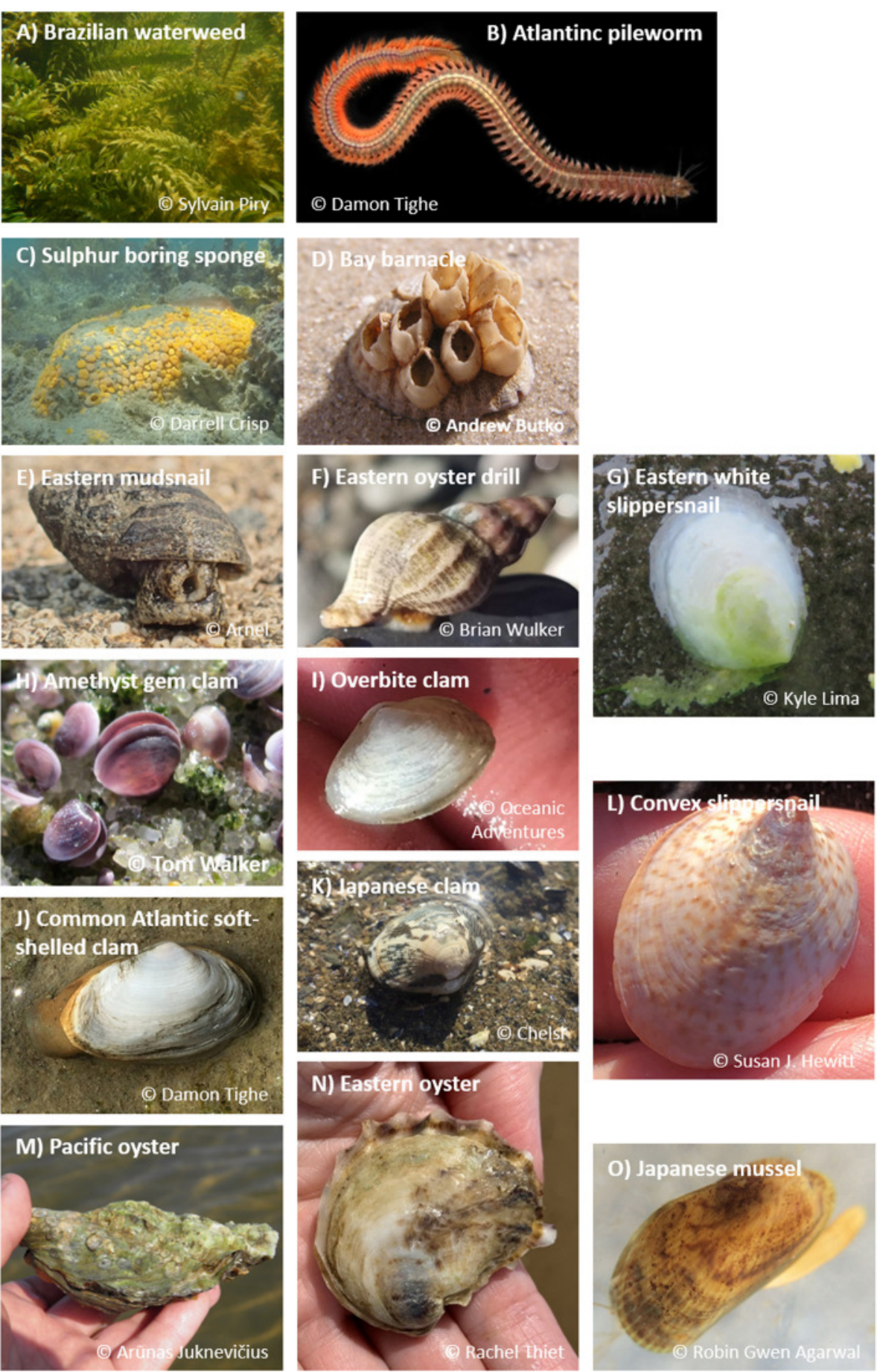

Figure 1

near the San Francisco Estuary was in 1964-1965, and is now common around the Estuary and Delta [2] (Figure 2C). In tropical regions, a disease called malaria is passed on to humans by mosquitoes, so introducing mosquitofish into rivers, lagoons, and ponds decreases the number of adult mosquitoes and the chances of people getting sick. Species that are good for fishing may also be intentionally introduced. That is why you can find striped bass and American shad in the Estuary (Figures 2D,E). 
Figure 2

Some of the vertebrate alien species present in the San Francisco Estuary and adjacent ecosystems. (A) Bluefin killfish; (B) goldfish;

(C) western mosquitofish; (D) striped bass;

(E) American shad;

(F) nutria; (G) red-eared slider (Photo credits: BioDiversity4All.org).

\section{BALLAST WATER}

Water carried inside the hulls of ships to balance them. When ships are loading cargo, ballast water is dumped to keep the ship from carrying too much weight.
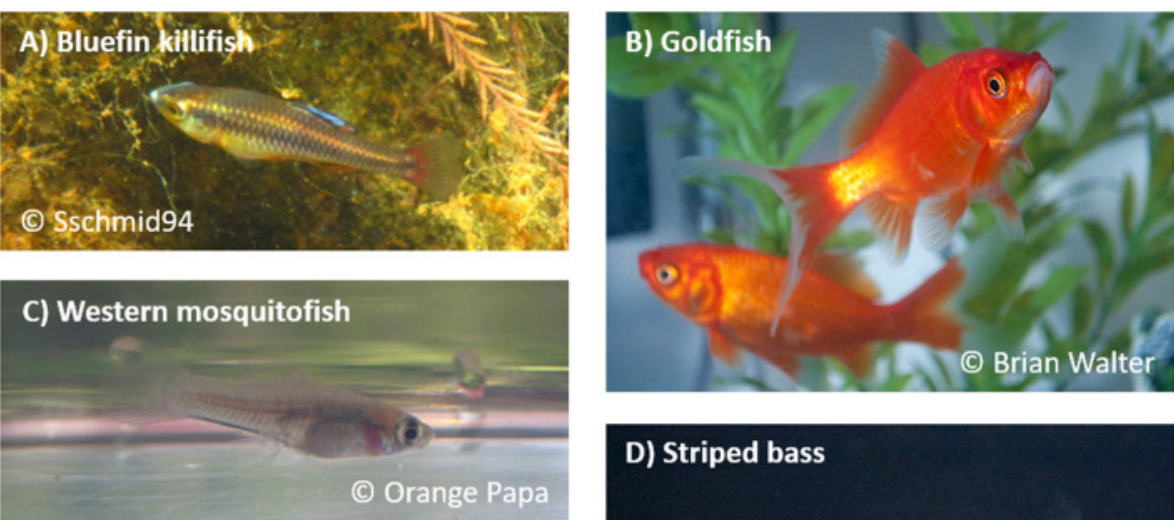

\section{D) Striped bass}

E) American shad
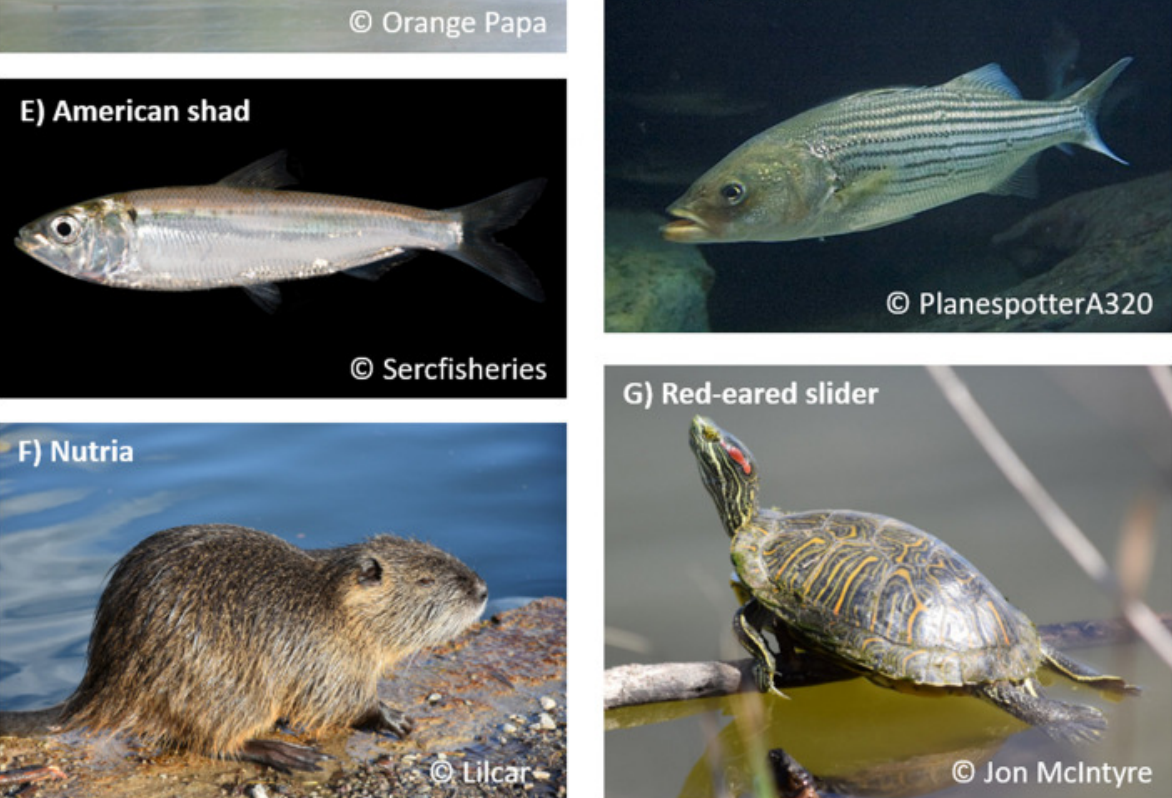

Figure 2

Intentional introductions may also result in unintentional introductions. The Pacific oyster and eastern oyster were introduced intentionally into the San Francisco Estuary in the late 1930s and 1800s, respectively (Figures $1 \mathrm{M}, \mathrm{N}$ ). Although these species did not successfully establish themselves in the Estuary, scientists noticed that many new alien species appeared around the same time. Some of these aliens hitchhiked attached to the oysters' shells or to the hulls of ships that brought the oysters, and some arrived in the ballast water of these ships. Several additional examples are shown in Figure 1.

Ballast water is one of the most common ways to unintentionally introduce alien species (Figure 3). Big transoceanic ships carry ballast water in their hulls to give them stability as they travel the ocean. This water can be full of living creatures that are ready to find a new home. When the ships take on cargo, they often dump their ballast water in ports, which can introduce alien species. In 2000, ships coming from overseas to the San Francisco Estuary dumped enough water to fill 840 Olympic swimming pools [5]. That is a lot of water... and potentially a lot of aliens! 


\section{Figure 3}

Ballast water can transport alien species. (A) Full ballast water tanks help to stabilize a ship when the cargo hull is empty. This water may contain plant and animal species. (B) Ships discharge ballast water and any alien species it contains, when they are in port loading cargo. (C) Ballast water tanks are empty when the ship is loaded with cargo. (D) New water-and a new set of organisms-is pumped into the ballast water tanks when the cargo is unloaded.

\section{INVASIVE SPECIES}

A species that finds a new place to live, away from its native area, and increases in number, sometimes causing negative impacts on native species and the ecosystem.
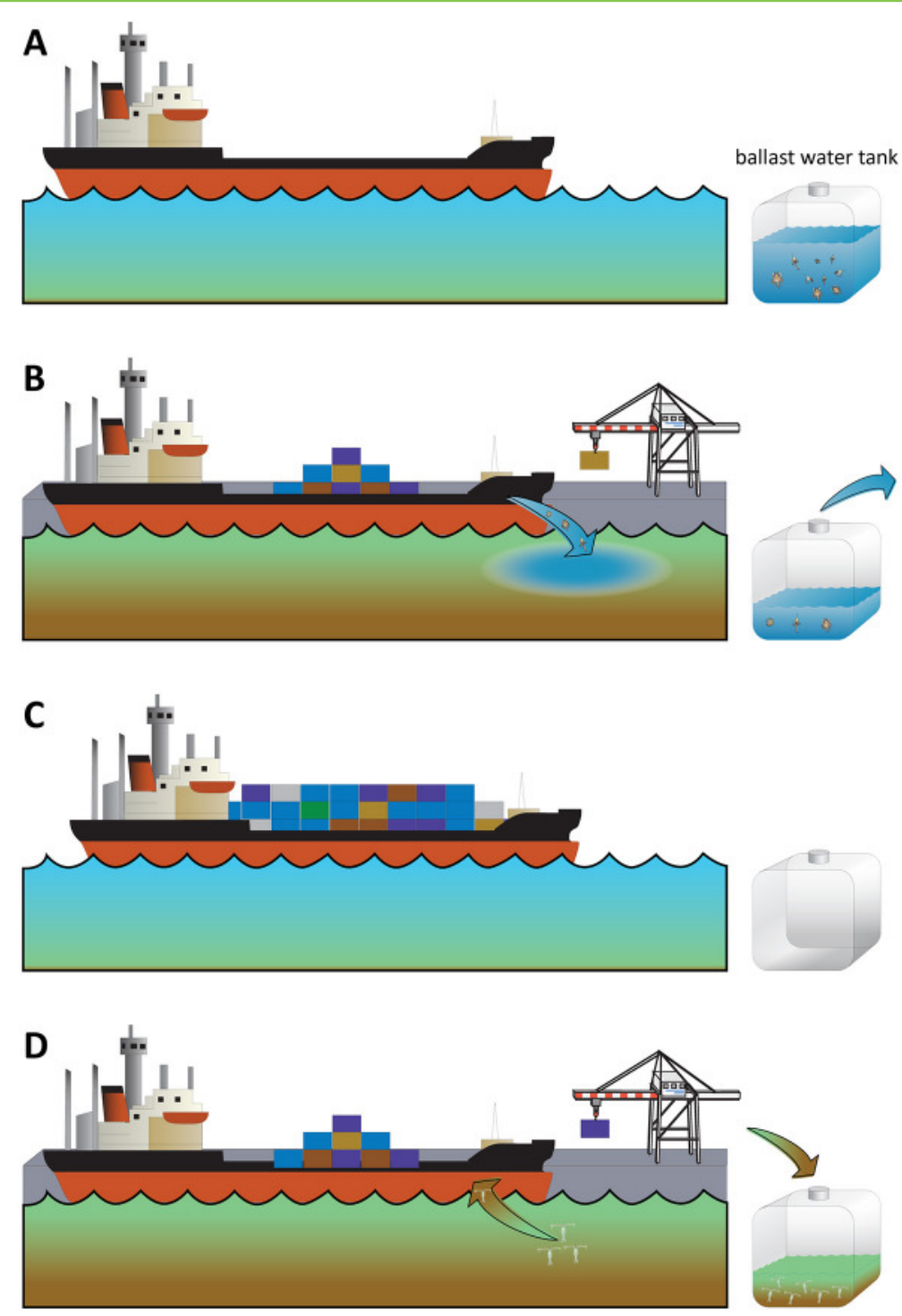

Figure 3

Alien species are also frequently introduced into new ecosystems from people's homes or aquariums. Some alien species were once someone's favorite pet, like goldfish and red-eared sliders (Figures $2 \mathrm{~B}, \mathrm{G})$, or may have been used to decorate an aquarium, like the Brazilian waterweed (Figure 1A).

\section{SOME ALIEN SPECIES BECOME INVASIVE}

When alien species arrive in a new place, some of them find the new environment too harsh, and they eventually die. However, other species find the environment to their liking and spread all over the place. When an alien species spreads widely in its new environment, often causing negative impacts on native species, it is called an invasive species. 
There are several reasons why some alien species become invasive. First, many invasive species can tolerate harsh environments, so they can live in places that are polluted or where the environmental conditions change often. These places tend to have few other organisms living there, which allows the alien species to settle in more easily and start a big family. Other alien species thrive because the parasites that affected them in their native environment are not present in their new home. Parasites delay the growth of any species, so if an alien species does not have parasites, each individual of that species will be healthier and able to reproduce more. Also, alien species often have fewer (or no) enemies in their new homes, because the native predators do not recognize the aliens as food. Over time, however, predators may learn that the alien species can be a good meal, which can halt its spread. Finally, many alien species become invasive species because they can reproduce in large numbers. So, when something bad happens, the alien species can recover more quickly than the native species.

\section{HELP SCIENTISTS DISCOVER ALIEN SPECIES}

Biologists (scientists who study living things) have come to realize that they can rely on farmers and fishers to help them understand how local ecosystems function and how the plants and animals in an area change over time. Other people with an interest in nature can also help biologists. Some biologists actively recruit and train people to help them with their work. These people become citizen scientists and help biologists gather precious information from a larger area and in a shorter time than the scientists could do on their own. Without the help of citizen scientists, it might take biologists years to do the same work. For example, citizen scientists are helping marine biologists to find alien species in Portugal and to discover how fast the invasive Atlantic blue crab is spreading [6].

\section{FIGHTING ALIENS}

Fighting alien species is expensive because they are difficult to eliminate, especially those hidden underwater. Strategies like fishing an invasive fish, dredging the sand to pick invasive clams, diving to pluck invasive algae, or scraping rocks to collect invasive mussels are never completely successful. These actions must be done over many years, and if a handful of aliens are left unharmed, the population will often bounce back within a few years. The best strategy to fight alien species is to avoid their introduction in the first place. To avoid the introduction of new species via ballast water, laws were created in 2017 stating that transoceanic ships can no longer dump ballast water when they arrive at a port; they must dump it in the ocean, far from the coast. We can all avoid introducing alien species by not releasing pet fish, turtles, or aquarium plants into nature. We can also be on the 
lookout for alien species in our areas, so that we can eliminate them before they spread and become invasive. Maybe you can become a citizen scientist, help biologists look for alien species, and help to keep these species from spreading.

Now that you know so much about alien species and how to fight them, share your knowledge with your friends and family. Ask scientists if they need help finding alien species and become a citizen scientist. You can find projects that you may like on many websites, like https://www.zooniverse.org, https://scistarter.org, https://science.nasa.gov/citizenscience, https://www.nps.gov/subjec ts/citizenscience/be-a-citizen-scientist.htm, or https://www.national geographic.org/idea/citizen-science-projects/. Small actions may lead to big changes, and you can be the one to spark the change in your neighborhood! We must all work together to protect our precious planet from the dangers posed by alien species.

\section{ACKNOWLEDGMENTS}

We truly appreciate the thorough revisions and detailed comments made by the reviewers and the editor, Dr. Nathan M. Good (University of California, Berkeley), which helped us to improve the original version of this article. This work received funds from Foundation for Science and Technology (FCT, Portugal) to CCMAR (UIDB/04326/2020) and CIIMAR (UIDB/04423/2020 and UIDP/04423/2020). JE has a Ph.D. scholarship (SFRH/BD/140556/2018) also funded by FCT. This is contribution \#1365 from the Coastlines and Oceans Division of the Institute of Environment at Florida International University.

\section{REFERENCES}

1. Shrader, K., Zierdt Smith, E. L., Parchaso, F., and Thompson, J. K. 2021. If You Give a Clam an Estuary: The Story of Potamocorbula. Available online at: https://kids.frontiersin.org/articles/10.3389/frym.2021.599289

2. Cohen, A. N., and Carlton, J. T. 1995. Nonindigenous Aquatic Species in a United States Estuary: A Case Study of the Biological Invasions of the San Francisco Bay and Delta. Report No. PB96-166525. Washington, DC: United States Fish and Wildlife Service; The National Sea Grant College Program-Connecticut Sea Grant.

3. San Francisco Estuary Magazine. 2020. Yet Another Non-Native Aquatic Species May Have Made Itself at Home in the Delta. Available online at: https://www. sfestuary.org/yet-another-non-native-aquatic-species (accessed October 17, 2020).

4. California Department of Fish and Wildlife. 2020. Discovery of Invasive Nutria in California. Available online at: https://wildlife.ca.gov/Conservation/Invasives/ Species/Nutria/Infestation (accessed November 23, 2020).

5. Falkner, M. B. 2001. California's Ballast Water Management and Control Program: Progress Report-January 2001. Long Beach, CA: California State 
Lands Commission.

6. Encarnação, J., Baptista, V., Teodósio, M. A., and Morais, P. 2021. Low-cost citizen science campaign effectively monitors the rapid expansion of a marine invasive species. Front. Environ. Sci. 9:752705. doi: 10.3389/fenvs.2021.752705

SUBMITTED: 27 December 2020; ACCEPTED: 28 September 2021; PUBLISHED ONLINE: 18 November 2021.

EDITED BY: Nathan M. Good, University of California, Berkeley, United States

CITATION: Morais P, Encarnação J, Teodósio MA and Dias E (2021) Aliens From an Underwater World. Front. Young Minds 9:646539. doi: 10.3389/frym.2021.646539

CONFLICT OF INTEREST: The authors declare that the research was conducted in the absence of any commercial or financial relationships that could be construed as a potential conflict of interest.

COPYRIGHT @ 2021 Morais, Encarnação, Teodósio and Dias. This is an open-access article distributed under the terms of the Creative Commons Attribution License (CC BY). The use, distribution or reproduction in other forums is permitted, provided the original author(s) and the copyright owner(s) are credited and that the original publication in this journal is cited, in accordance with accepted academic practice. No use, distribution or reproduction is permitted which does not comply with these terms.

\section{YOUNG REVIEWER}

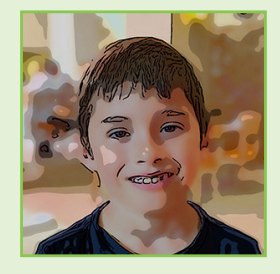

\section{NIKO, AGE: 8}

I love Pokemon and soccer. I love writing about animals. My favorite books are about dinosaurs and predators.

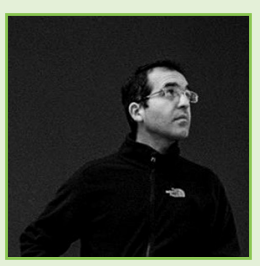

\section{AUTHORS}

\section{PEDRO MORAIS}

My passion for marine biology began when I was 7 years old. I went on vacation with my parents and sister to a lovely beach in southern Portugal. There, I spent all the time I could in the tide pools searching for fishes, crabs, shrimps, and anemones. I have studied all kinds of aquatic organisms (bacteria, microscopic algae, jellyfish, clams, crabs, birds, fish, and even whales and dolphins) from the deep ocean to shallow lagoons, estuaries, rivers, lakes, and streams. During my free time, I enjoy dancing tango, taking photographs, woodworking, fixing and restoring old things, and researching my ancestry. *pmorais@ualg.pt

\section{JOÃO ENCARNAÇÃO}

For as long as I remember, the ocean has been my backyard and my playground. At first I fished and surfed, and then I started to look into the underwater world with more attention. This happened during my first SCUBA diving course in 2009. At the same time, underwater photography became another big passion of mine! 


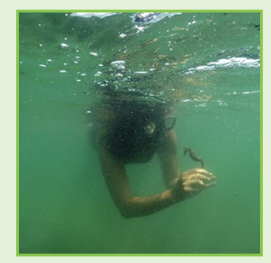

Meanwhile, I completed a degree in marine biology so that I could identify all the fish species I saw underwater. I have studied the impacts of dams on estuarine species and the effects of natural freshwater springs on marine coastal biodiversity. Now, I am doing a Ph.D. and studying aquatic invasive species in Southern Portugal.

\section{MARIA ALEXANDRA TEODÓSIO}

I was born in a small town in southern Portugal, surrounded by salt marshes and the Guadiana Estuary. I learned to like the smell and dark color of the estuary, and discovered that there are amazing treasures hidden underwater. When I was a teenager, I followed my father to rescue a sunken boat in the estuary. Then, I followed my waterway, and as a river always finds the sea, I went to the University of Algarve to study marine biology. For the last 30 years, I have been a professor and scientist at this University. I like to teach and study estuarine ecology and biological oceanography. My specific research interests include studying the nutritional condition of marine organisms and how global change impacts marine biodiversity. For fun, I like to paint everything, from furniture to walls and, sometimes, even "real paintings."

\section{ESTER DIAS}

I am a researcher at the Estuarine Ecology and Biological Invasions Research Group (CIIMAR-University of Porto, Portugal). As a child, I was curious about how animals behave, what they eat, and why they need to migrate long distances to reproduce. So, becoming a biologist was my chance to find the answer to these questions. So far, I have studied small aquatic animals called zooplankton (some only $1 \mathrm{~mm}$ long), clams, aquatic birds, fish, and even marine mammals. Currently, I study the migrations of fish, the impacts of biological invasions, and what is on the menu of each aquatic species. 